\title{
From 'Do No Harm' to Doing More Good Extending the UN Framework to Connect Political CSR with Business Responsibilities for Human Rights
}

\author{
Jonsson, Jonas; Fisker, Mette; Buhmann, Karin
}

Document Version

Final published version

DOI:

$10.2139 /$ ssrn.2962360

Publication date:

2016

License

Unspecified

Citation for published version (APA):

Jonsson, J., Fisker, M., \& Buhmann, K. (2016). From 'Do No Harm' to Doing More Good: Extending the UN Framework to Connect Political CSR with Business Responsibilities for Human Rights. Centre for Business and Development Studies. CBDS Working Paper No. 26 https://doi.org/10.2139/ssrn.2962360

Link to publication in CBS Research Portal

\section{General rights}

Copyright and moral rights for the publications made accessible in the public portal are retained by the authors and/or other copyright owners and it is a condition of accessing publications that users recognise and abide by the legal requirements associated with these rights.

\section{Take down policy}

If you believe that this document breaches copyright please contact us (research.lib@cbs.dk) providing details, and we will remove access to the work immediately and investigate your claim. 


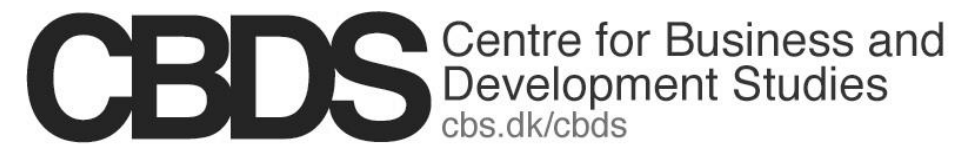

Copenhagen Business School HAN DELSH ØJ SKOLEN

By Jonas Jonsson, Mette Fisker and Karin Buhmann 02/11/2016

CBDS Working Paper Series

Working Paper Nr. 26, 2016 


\section{Table of Contents}

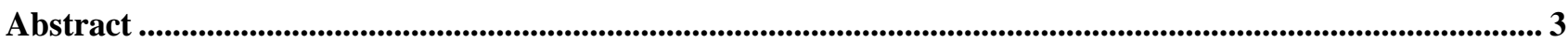

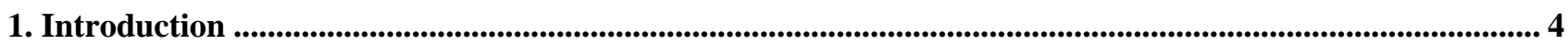

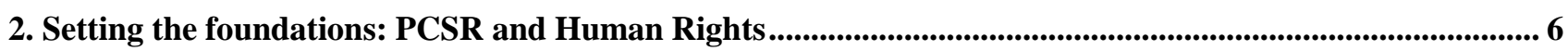

2.1 Corporations as Political Actors .......................................................................................................................... 6

2.2 Business and Human Rights..................................................................................................................................................... 8

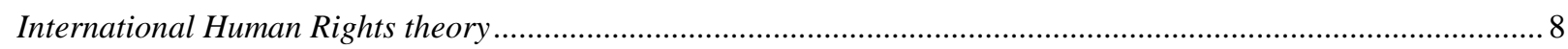

Critical views on the UN Framework and human rights fulfilment …………………...................................... 11

2.3. Summing up: knowledge gaps and implications for theory development................................................ 13

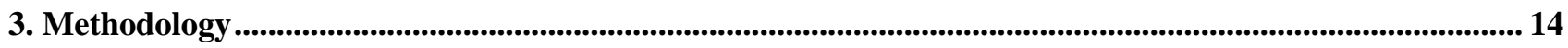

4. Analysis: Exploring implications of PCSR and the UN Framework towards human rights fulfilment ..... 17

4.1. The relevance of the UN Framework as a platform for developing PCSR guidance............................... 17

4.2. How firms may to contribute to fulfilling human rights................................................................................... 19

4.3. Drawing insights from the cases to move from 'respect' to 'fulfil' human rights .................................... 20

5. Extending the UN Framework to contribute to PCSR with a focus on human rights fulfilment.................. 21

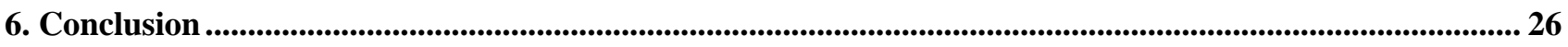

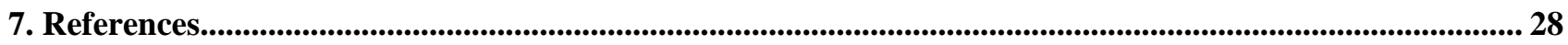




\title{
From 'do no harm' to doing more good: Extending the UN Framework to connect Political CSR with Business Responsibilities for Human Rights
}

\author{
by \\ Jonas Jonsson, Mette Fisker and Karin Buhmann ${ }^{1}$
}

\begin{abstract}
The literature on Political CSR (PCSR) outlines the political role of corporations, but fails to offer concrete suggestions for businesses to fill governance gaps through provision of public goods. Conversely, the political role of Multi-National Enterprises (MNEs) plays a limited part in the UN Framework on Business and Human Rights, which was adopted by the UN in 2008 and forms the basis for the 2011 UN Guiding Principles on Business and Human Rights. This paper contributes to connecting the two approaches by drawing on insights from the PCSR literature to theorize on the extent of human rights responsibilities of MNEs, and combining this with the human rights focus of the UN Framework. Drawing on existing literature's coverage of MNEs operating in developing countries, we discuss how businesses can improve the respect and fulfilment of human rights. We propose an 'Extended UN Framework' to help attribute political responsibilities to MNEs that reflect their political power. The Extended Framework combines the original UN Framework's 'do no harm' approach with a leverage-based approach for firms to contribute to delivering public goods that are human rights.
\end{abstract}

Keywords: Due Diligence, Human Rights, Leverage, Moral Legitimacy, Political CSR, UN Framework

\footnotetext{
${ }^{1}$ Karin Buhmann is Professor of Business and Human Rights, CBS. Jonas Jonsson and Mette Fisker study MSc in Business, Language \& Culture (Business \& Development Studies) at CBS
} 


\section{CBDS Working Paper \\ From 'do no harm' to doing more good: Extending the UN Framework to connect Political CSR with Business Responsibilities for Human Rights}

\section{Introduction ${ }^{2}$}

Despite almost a century of human rights treaties on states' obligations to protect, respect and fulfil human rights and recent decades' attention to human rights as part of Corporate Social Responsibility (CSR), human rights violations and deprivations suffered by a vast number of people in many countries around the globe persist. Many human rights violations are directly or indirectly caused by business firms, particularly by Multi-National Enterprises (MNEs), operating in countries that suffer from governance gaps and institutional voids (Ruggie 2013, Zerk 2006). These problems refer to the inability of many states to effectively implement and enforce regulation within their own territory, and the weakness and inability of transnational regulation to address transnational challenges (Habermas 2003). Such problems exacerbate the limitations that many individuals, especially in countries suffering from institutional voids, encounter with regard to access to basic human rights such as education and health care. Particularly outspoken in poor countries (Osuji and Obibuaku 2016), those deprivations are part of a vicious circle of poverty that forces workers to accept sub-standard working conditions and highly contextually complex practices such as child labour (Kolk and van Tulder 2004), and induces governments to offer MNEs investment opportunities that practically permit adverse human rights impacts. As recognised by the United Nations' (UN) Sustainable Development Goals (SDGs) and their predecessor the Millennium Development Goals (MDGs), enhanced provision of education and health services are crucial steps out of such adverse circumstances. Yet many states lack the capacity to provide the required institutions and financial and human resources, leading to insufficient fulfilment of human rights, which are due to individuals according to human rights theory and states' international obligations.

In recent decades, civil society and governments have increasingly been pressuring companies to become more socially responsible and address a variety of social problems, including human rights (Kolk 2016). Yet, despite a myriad of voluntary Corporate Social Responsibility (CSR) initiatives, business related human rights abuses remain widespread and severe (Human Rights Watch 2016). Acknowledging a need to involve MNEs in solutions to global human rights problems, the UN after a lengthy process marked by initial failures (Kinley, Nolan \& Zerial 2007; Knox 2012) adopted the UN Protect, Respect and Remedy Framework on Business and Human Rights ('UN Framework') in 2008. For pragmatic political reasons governed by the aim of reaching agreement on a partial solution rather than seeking to solve all problems at the risk of no agreement at all (Buhmann 2012; Ruggie 2016; 2013), the UN Framework limits the corporate responsibility to respect human rights, that is, to a so-called negative responsibility to 'do no harm'. The positive responsibilities to protect and fulfil human rights were attributed to nation-states only. Arguably, this sharp separation of responsibilities may be suitable for states with well-functioning regulatory capacity.

\footnotetext{
${ }^{2}$ This paper was presented at the SAFIC conference at Copenhagen Business School, April 2016. We are grateful to the audience for useful comments.
} 


\section{CBDS Working Paper \\ From 'do no harm' to doing more good: Extending the UN Framework to connect Political CSR with Business Responsibilities for Human Rights}

Considering the limited capacity of governments in many countries, however, the exclusive reliance on nation-states to fulfil human rights results in many individuals and communities suffering inadequate access to a range of public goods that are human rights. Among the most severe are access to education and health services, including medicine and adequate diagnostic treatment. Importantly, the UN Framework does not reject the relevance of corporations fulfilling human rights.

Recognising the many-facetted power of MNEs, the literature on Political CSR (PCSR) assumes an understanding of MNEs as not just economic actors but also 'political' actors in the sense that they contribute to filling institutional voids by self-regulating to conform to policy needs and by providing public goods (Scherer et al. 2016, Scherer \& Palazzo 2007, 2011). This political role transcends the UN Framework's separation of corporate responsibilities and state duties. Critiques and reviews of the PCSR literature has identified a need for PCSR theory to become less abstract and pay more attention to how managers may assess specific responsibilities of corporations to act 'politically' and contribute to filling governance gaps (see Scherer et al. 2016 for an overview). Moreover, little research deals explicitly with PCSR interventions to fulfil human rights. This suggests a need for academic exploration to clarify how to determine the political responsibilities of MNEs in relation to human rights fulfilment, and to enhance the connection between theory and operational guidance for managers.

This article contributes towards filling that knowledge gap with a particular focus on the role of MNEs. Our research objective is to offer a theory-based approach to the corporate responsibility towards human rights that is more nuanced than the current UN Framework and at the same time responds to the literature's critique of PCSR abstractionism and to the business ethics literature's critique of the UN Framework as having a too limited focus. We combine the PCSR literature with the operational focus of the UN Framework on Business and Human Rights, while taking into account critique of the limited attention paid by the UN Framework to corporate human rights fulfilment. A selection of literature-based cases offer insights on diverse situations in which MNEs may have negative or positive human rights impacts. Based on an analysis of these within the set theoretical basis we propose an extension of the UN Framework to help MNEs identify needs and capacity and make relevant decisions on how they can assume political CSR by contributing to human rights fulfilment.

The article proceeds as follows. Section 2 offers an overview of state-of-the-art of theory on corporations as political actors and on business responsibilities for human rights, including critique of the UN Framework. 


\section{CBDS Working Paper \\ From 'do no harm' to doing more good: Extending the UN Framework to connect Political CSR with Business Responsibilities for Human Rights}

Section 3 explains the methodology. Sections 4 and 5 constitute the main analytical body and lead to the development of the extended UN Framework. Finally, section 6 concludes and outlines future research and implications.

\section{Setting the foundations: PCSR and Human Rights}

\subsection{Corporations as Political Actors}

PCSR theory is a relatively broad strand of CSR literature that focuses on what has come to be understood as the political role and responsibilities of corporations (Frynas and Stephens 2015). This 'political' role occurs, i.a. when corporations actively contribute to the delivery of tasks or goods that are generally considered state obligations (Scherer et al. 2016). The pertinence of businesses assuming such a PCSR role is linked to the lack of resources or will of national governments to sufficiently address transnational challenges such as corruption, global warming and human rights implementation. While such problems may occur in all countries, problems related to the delivery of specific governmental services or tasks that correspond to states' positive human rights duties to fulfil human rights are particularly acute in developing countries. This causes opportunities or according to some views even responsibilities for businesses, and is directly related to the core of PCSR that focuses on the role of MNEs (and other firms) to step in as political actors that complement or even take over from the state in delivering important services to society. PCSR literature treats MNEs as being in a unique position to contribute solutions to these challenges due to their size and transnational nature that allows for resources and insights into needs and practices (Scherer and Palazzo 2007, 2011). Yet recent reviews of the PCSR literature identify an urgent need to operationalise PCSR so as to provide more concrete advise to MNEs on how they may determine how to undertake political roles (Frynas and Stephens 2015; Scherer et al 2016).

Developments in past years have pushed the CSR debate towards a broader focus that increasingly recognises that CSR is not just voluntary business actions that are separated from the law (Dentchev, van Balen \& Haezendonck 2015; Buhmann 2006), but also increasingly related to implicit or explicit governmental needs. The is reflected in solidifying recognition in the organisational and business ethics literature of the role of governmental institutions in shaping CSR norms and firms' CSR activities (Matten \& Moon 2008; Gond, Kang \& Moon 2011; Gjølberg 2010, Buhmann 2016). However, such governmental shaping of business conduct for CSR to contribute to public policy objectives, whether implicit or explicit, mainly occurs in states with strong governments, whether industrialized or emergent. Governments in several developed states are deploying CSR as a soft modality to regulate activities of firms beyond their own territories, in particular in order to promote public policy objectives on human rights in emerging economies and developing countries 


\section{CBDS Working Paper \\ From 'do no harm' to doing more good: Extending the UN Framework to connect Political CSR with Business Responsibilities for Human Rights}

(Gjølberg 2011, Buhmann 2013). This, too, suggests that MNEs can assume political tasks that benefit from their transnational reach, resources and insights gained from their broad operations. Yet, research makes critical CSR scholars question the assumption that CSR can contribute to development in the Global South (Lund-Thomsen \& Lindgreen 2013; Lund-Thomsen, Lindgreen \& Vanhamme 2014). The abstraction of the general lines of the PCSR literature in combination with critical CSR scholarship suggests gaps in our knowledge on how resourceful and CSR-committed MNEs determine how they may best and most relevantly identify the needs to which they may contribute.

Recognising that MNEs increasingly participate in the political sphere by responding to government failures and substituting governmental action, PCSR theory departs from the instrumental approach that builds on the conjecture that national governments work effectively and provide legal and moral guidance, and that the corporation is solely a private economic actor (Jones 1995, Sundaram \& Inkpen 2004). The PCSR literature theorizes on the role of MNEs assuming 'corporate citizenship' by filling institutional voids, particularly in weak governance zones (Scherer \& Palazzo 2011, Vogel 2008). Matten, Crane and Chapple (2003: 116) argue that PCSR occurs when corporations take over essentially governmental functions with regard to the protection, facilitation and enabling of citizens' rights. According to this view, national governments are no longer the sole guarantor of social, political and civil rights (Margolis \& Walsh 2003, Matten \& Crane 2005, Hertz 2001) as corporations increasingly provide public goods or services, often related to the specific sector or industry of the particular MNE. For instance, a pharmaceutical company may not only sell drugs in the market, but may also actively train hospital personnel and deliver capacity building in healthcare.

Corporations may self-regulate to improve working conditions and ensure participation in decision-making, which are not only conventionally considered governmental responsibilities but also constitute human rights. ${ }^{3}$ Corporate action to provide public goods and administer access to services of an intrinsic human rights character, where the government's delivery is limited due to institutional voids, constitutes PCSR.

The motivations for MNEs to take on political responsibility are a subject of controversy. Institutional theory explains how MNEs respond to institutional pressures, often divided into three varieties: coercive, normative and mimetic (DiMaggio \& Powell 1991), of which the first two are of particular interest in the current context. Coercive institutional pressures are typically relatively strong in developed countries with strong states that can implement and enforce regulation, and thereby constitute major drivers of socially responsible behaviour. However, studies of developing countries that may be characterised as weak states have pointed to the substantial impact of normative institutional pressure by civil society, pressuring firms to behave

\footnotetext{
${ }^{3}$ Working conditions and public participation are covered by the Universal Declaration of Human Rights (art. 21 and 23), the International Covenant on Civil and Political Rights (art 25), the International Covenant on Economic, Social and Cultural Rights (art 7), ILO core conventions, and the Vienna Declaration and Programme of Action.
} 


\section{CBDS Working Paper \\ From 'do no harm' to doing more good: Extending the UN Framework to connect Political CSR with Business Responsibilities for Human Rights}

responsibly in the absence of significant coercive pressure by the state (Nurunnabi 2015; Campbell 2007; Jamali, Safieddine \& Rabbath 2008). As a result, MNEs' 'social licence to operate', entailing social acceptance of their activities, increasingly depends on moral legitimacy (Demuijnck and Fasterling 2016; Suchman 1995; Palazzo \& Scherer 2006). Moral legitimacy rests on "judgments about whether the activity is 'the right thing to do' (...) [reflecting] beliefs about whether the activity effectively promotes societal welfare" (Suchman 1995: 579). Thus, the growing pressure on corporations from NGOs and civil society may help convert MNEs into part of the solution to institutional voids, rather than being the problem. Importantly, moral legitimacy in areas such as human rights comprises both consequential legitimacy (measured by concrete accomplishments, like increased access to health services or education) and procedural legitimacy, central to which is participation in decision-making (Suchman 1995). Adopting a communicative multistakeholder approach is significant for corporations to gain both consequential and procedural legitimacy (Swanson 1999, Rasche \& Gilbert 2012). Such an approach increases the comprehensiveness of the understanding of stakeholder interests, in turn increasing the likelihood that such actions are appropriate and relevant to stakeholders, including those that are disadvantaged or have particular needs, such as access to social human rights. Moreover, stakeholder communication and consultation, both of which are emphasised by the UN Framework, promote the human right of popular participation in decision-making (OECD 2016).

As moral legitimacy is becoming "the decisive source of societal acceptance for corporations in an increasing number of situations" (Palazzo \& Scherer 2006: 10), there is a need for an improved understanding of the responsibilities of business in the political sphere. This is both in the interest of civil society and governments, who can apply normative and coercive pressure to corporations, and in the interest of MNEs that strive to be perceived as morally legitimate. PCSR underpins the argument that MNEs can indeed be social and political actors as well as economic actors, and as such must be attributed social and political responsibilities that reflect their power and influence. Yet, the literature on PCSR has paid little attention to the specific steps for corporations to honour the moral obligations that go hand in hand with their increased political power.

\subsection{Business and Human Rights}

\section{International Human Rights theory}

While the operational element is lacking in PCSR theory, the normative guidance on business responsibilities for human rights developed by the $\mathrm{UN}$ in recent years has made a targeted effort to construct a normative framework for assessing the human rights responsibilities of businesses with operational implications. For normative structuring, the UN's Business \& Human Rights (BHR) regime has taken point of departure in international human rights theory, which itself is based on international law that has traditionally had a predominant state-centrist focus (Shelton 2014). As a result, the conventional international human rights 


\section{CBDS Working Paper \\ From 'do no harm' to doing more good: Extending the UN Framework to connect Political CSR with Business Responsibilities for Human Rights}

regime has primarily been concerned with the three-pronged obligation of governments to respect human rights (observe the rights), protect human rights (against violations) and fulfil human rights (providing for health services, education etc.) (Tomuchat 2008). However, as the PCSR literature notes, vast gaps persist in all these areas. Governance gaps and inefficient institutions enable not only states but also businesses to cause abuse of human rights (Arnold 2010, Habermas 2003). While firms of all sizes and types may cause human rights impacts, many complaints relate to MNEs (UN 2008). The problem of business-caused human rights harm is particularly prevalent in developing countries (Guiliani and Macchi 2014), which also often suffer from inadequate state fulfilment of rights (Ruggie 2013).

Concerns about the ability of firms to cause human rights abuse and evidence that this results from governance gaps played a strong part in the establishment of the UN Global Compact (UNGC) in 2000. The UNGC comprises ten principles to which businesses commit on a voluntary basis in four issue areas: human rights, labour rights, environment and anti-corruption. Despite its many merits, the UNGC remains a voluntary instrument that encourages businesses to do good rather than attributing responsibility (Nolan 2005, Buhmann 2009). The so-called UN Norms on Business and Human Rights were drafted 1998-2003 by a UN Expert Group but never formally adopted (Knox 2012). One of the contentious points in the Norms was the statement that MNEs have the obligation to "promote, secure the fulfilment of, respect, ensure respect of and protect human rights recognised in international as well as national law (...) within their respective spheres of activity and influence" (UN 2003 Art. A.1). Thus, the text of the UN Norms not only implicitly acknowledged that businesses are political actors, but also attributed legal responsibility to MNEs to positively improve the human rights situation. The UN Norms were criticized on a number of accounts, including for not clearly delineating corporate responsibility in relation to state duties. It was considered a radical step to legally impose obligations upon companies under international law to not only respect human rights, but also protect and fulfil human rights within an ill-defined sphere of influence (Horrigan 2010). Eventually, despite noting that they contained "useful elements and ideas for consideration" (UN 2004), the UN Commission on Human Rights rejected the Norms.

The Commission decided instead to launch a major study, which in 2005 was commissioned to Professor John Ruggie, a Harvard academic who undertook this UN mandate as Special Representative of the Secretary-General ('SRSG'). Following a logic of 'principled pragmatism', Ruggie in his role as SRSG was determined to create political results (Knox 2012). The three-year study led to the UN Framework (UN 2008) that was unanimously accepted by the UN Human Rights Council. Inspired by the three-pronged distinction between states' obligations to respect, protect and fulfil, the UN Framework is based on three 'Pillars': the state duty to protect against human rights abuses by third parties (such as companies), the corporate 


\section{From 'do no harm' to doing more good: Extending the UN Framework to connect Political CSR with Business Responsibilities for Human Rights}

responsibility to respect human rights, and obligations of both states and businesses to offer effective remedy mechanisms when human rights abuse is perceived to have occurred (UN 2008). Launched as a policy document and applying to firms of all types regardless of size, the Framework abstains from language that seeks to impose legal obligations. The wording deployed by the Framework in relation to the second Pillar is suggestive of soft law, which in the international law context entails morally and politically binding norms but not legally binding obligations (Shelton 2014). Soft law excludes the possibility of formal enforcement through legal sanctions, but enforcement may take place through other modalities than the conventional legal institutions. Thus, the UN Framework refers to the 'courts of public opinion', “comprising employees, communities, consumers, civil society, as well as investors" (UN 2008 para. 54) that hold corporations accountable for their actions in economic and reputational terms. Under a second mandate as UN SRSG, Ruggie was asked to 'operationalise' the UN Framework. This resulted in the UN Guiding Principles on Business and Human Rights or in short, UNGPs (UN 2011), which offer detailed guidance for firms and states to implement the UN Framework. As part of that operationalisation, the UNGPs elaborate steps that companies should take to discharge their responsibility to respect human rights. A policy commitment and a human rights due diligence process to map and address its impact are key among those steps. The UNGPs recognise that the specific actions vary depending on the nature and context of the operation, the size of the business and the risk of severe human rights impact.

While a due diligence approach is well known from corporate law as a process to identify and limit (typically financial or legal liability) risks to the firm, the UN Framework shifts the focus to risks caused by the firm to society (Buhmann 2015). The human rights due diligence process serves to reduce business-related human rights abuses by helping firms become aware of, prevent and address adverse human rights impacts of the company (UN 2008). The process is guided by three factors: firstly, the context of the country in which the business activities take place in order to identify specific human rights issues; secondly, the human rights impacts that the activities of the company itself may have in that context; thirdly, the company's indirect contribution to human rights abuses through their relationships to other actors, for example in their supply chain. The UN Framework strove to work around problems that led to the abandonment of the UN Norms by clearly demarcating the corporate responsibilities and state duties, and by clearly defining the corporate responsibility to 'respect'. In this context, the concept of 'leverage' was introduced to indicate that companies should use their influence to change practices with business partners or governments, and collaboration with human rights experts was recommended (UN 2011 paras. 16-19). The reference for firms to use their leverage invites a manager to consider the firm's opportunity to make a change in the specific context in which it operates. The exercise of leverage is an integrated part of human rights due diligence according to the UNGPs (UN 2011 para 19(b)), but leverage is also important in its own right as a modality to affect change with local institutions or practices through the company's economic muscle, which in itself may have political 


\section{CBDS Working Paper \\ From 'do no harm' to doing more good: Extending the UN Framework to connect Political CSR with Business Responsibilities for Human Rights}

connotations. This occurs for example where a local or national government is dependent on the company for finance, jobs, knowledge, and service provision. The UN Framework implicitly underscores the power of leverage as part of efforts to reach solutions to BHR issues (UN 2008 para. 101).

In line with CSR studies on the need for CSR activities to be anchored with the top management for policies to effectively spread to the relevant parts of the organisation to take action (Roepstorff 2010; Maon, Lindgreen \& Swaen 2009), the UN Framework notes that the policy commitment should be approved at the most senior level of the business enterprise (UN 2011 para. 16(a)).

The development of the UN Framework and UNGPs involved a broad range of stakeholders, including businesses, ensuring a relatively high degree of legitimacy and support for the adoption (Knox 2012, Buhmann 2012) despite later critique (see e.g., Deva 2013; Melish and Meidinger 2012). The significance that the UNGPs have had in practice has been confirmed by the strong uptake by firms (Business and Human Rights Resource Center website) and influence on major codes to govern business activity (Buhmann 2016).

While the UN Framework and the UNGPs do recognise that firms may contribute to human rights in positive ways, they limited their focus to the negative corporate responsibility to respect human rights, i.e. to 'do no harm' (UN 2011). That decision reflected a pragmatic assessment of what was deemed feasible for political support for the outcome of the mandate process in view of previous efforts that had faltered, including the UN Norms, combined with an explicit recognition of the need to reduce business-related human rights harm and secure victims against business related abuse (Knox 2012, Ruggie 2013).

\section{Critical views on the UN Framework and human rights fulfilment}

The knowledge and guidance offered by the UN Framework and the UNGPs, have been described by their author, Professor John Ruggie, as a work in progress for the evolution of theory and practical guidance on business responsibilities for human rights. Ruggie noted that the output of the six-year mandate will not be the end of business and human rights challenges, but that they may constitute "the end of the beginning: by establishing a common global platform for action, on which cumulative progress can be built, step-by-step, without foreclosing any other promising longer-term developments" (UN 2011, see also Martin 2012). While the Framework and UNGPs have been subject to critical voices particularly among business ethicists, but also among lawyers, they have also been recognised by scholars of international business, human rights and CSR as ground-breaking in view of previous stalemates (e.g., Kolk 2016; Buhmann 2012), and as offering an important foundation for further refinement (Wettstein 2015, Sanders 2015, De Felice 2015). 


\section{CBDS Working Paper \\ From 'do no harm' to doing more good: Extending the UN Framework to connect Political CSR with Business Responsibilities for Human Rights}

A common point of departure for the business ethics critique of the UN Framework turns on an alleged disregard of human rights as moral obligations that are due full respect and fulfilment efforts by all societal agents. This philosophically grounded critique is concerned that the UN Framework, and consequently also the UNGPs, are too unambitious in terms of preventing human rights abuse and fulfilling human rights (Fasterling and Demuijnck 2013). The gist of the business ethics critique is that in considering corporations "specialized economic organs, not democratic public interest institutions" (UN 2008: 16), the UN Framework overlooks the political and social power of corporations (Cragg 2012, Wettstein 2013). The Framework's instrumentalist view of firms has further been criticized for "stripping corporate responsibility to its bare minimum" (Wettstein 2015: 165) by assigning only negative duties that from a philosophical perspective are already universal and apply to all agents in society. This literature rejects the rationale that assigning positive duties to corporations entails a risk of external stakeholders becoming dependent on MNEs to provide human rights fulfilment where the government fails to do so. Informed by international development studies rather than human rights per se, other scholars offer a more general warning that non-state actors taking over functions normally considered governmental responsibilities may undermine state capacity and legitimacy and lead to an unsustainable dependence on MNEs to provide for essential public goods (Kolk \& Lenfant 2013, Idemudia \& Ite 2006).

Addressing this concern, some critics of the UN Framework have argued that there is a need for additional duty bearers that have back-up duties in case the primary duty bearer (i.e. the government) fails to deliver. According to Kolstad (2012), assigning duties only to primary duty bearers (states) presupposes an 'optimal division of moral labour' where the state always discharges its obligations in a fully and therefore optimal way, and where business actors are purely economic actors. Since reality rarely reflects such an optimal division of moral labour, Kolstad argues that without entities such as corporations having a backup role, human rights will not be fulfilled to the optimal extent (2012: 280). However, the responsibilities of corporations should only substitute governmental responsibilities insofar as the government is unable to live up to its obligations. Kolstad (2012) argues that when the government does have the means to fulfil and protect human rights but fails to do so, corporations should seek to influence and pressure the government to fulfil its obligations. Thus, positive duties for corporations differ based on governmental capacity to rectify the given human rights problem. Importantly, the term 'government' can refer to different levels of government - i.e. national, regional or local governments - depending on which governmental body is estimated by the MNE to have authority in the given situation and be best equipped to take effective action.

Based on the idea of moral legitimacy, it has been argued that companies that take on governmental responsibilities or pressure the primary duty bearer should adopt a multi-stakeholder approach, ideally involving both civil society and government. This would not only secure the company's moral legitimacy and 


\section{CBDS Working Paper \\ From 'do no harm' to doing more good: Extending the UN Framework to connect Political CSR with Business Responsibilities for Human Rights}

the best human rights outcome, but could also build governmental capacity to address the human rights issue and pressure governments to assume responsibility (Kolk \& Lenfant 2013). Moreover, corporate interventions to improve human rights can apply pressure by showcasing the failure of the government to address human rights within its own territory. That way, corporate back-up duties are argued to enhance rather than undermine the accountability of the state and increase the likelihood that it will perform its duties (Kolstad 2012: 280).

Finally, studies are moving towards a leverage-based approach to human rights responsibility, where responsibility is derived from the corporation's ability to exert influence through various forms of engagement with their public or private business relations (van Huijstee et al. 2016) and engage politically through measures to deliver public goods taking account of the context and local complexities (Scherer et al. 2016). The implication is that corporations need to take responsibility based on a pragmatic assessment of their capacity, their sectoral strength, and their opportunities for leverage in the context of the human rights problem. Delineating positive duties according to such a leverage-based approach is not an uncommon way of assigning human rights responsibility. For example, Article 2(1) of the International Covenant on Economic, Social and Cultural Rights asserts that member states are obligated to "... take steps (...) to the maximum of its available resources, with a view to achieving progressively the full realization of the rights recognized in the present Covenant by all appropriate means..." (UN 1966). While this particular example refers exclusively to the responsibility of states to fulfil human rights, it illustrates how it is indeed viable to expect of duty-bearers to assess their human rights responsibility to contribute to providing public goods in the light of what they can do.

\subsection{Summing up: knowledge gaps and implications for theory development}

The review of literature shows that there is a knowledge gap in theory on how MNEs and other firms may explicitly contribute to fulfilling human rights as part of PCSR. While the PCSR literature provides a comprehensive account of corporations as political actors, it does not suggest operational guidelines for businesses to discharge their moral obligations. Based on an ongoing advancement of international human rights theory to encompass the role and influence of firms, the Business and Human Rights theory provides such an operational framework through the UN Framework. Business ethics scholars have criticised the Framework for being set in an instrumentalist perception of the firm and for disregarding its political role to deliver public goods. The critique argues that this instrumentalism fails to optimise the contributions that firms can make to human rights.

In view of past failures to reach agreement on norms for businesses in relation to human rights, despite its 


\section{CBDS Working Paper \\ From 'do no harm' to doing more good: Extending the UN Framework to connect Political CSR with Business Responsibilities for Human Rights}

weaknesses the UN Framework remains a ground-breaking step in the evolution of theory and guidance on human rights responsibilities for corporations. As a work in progress for business responsibilities for human rights, The UN Framework offers a theory-based point of departure for further refinement and evolution and as a solid basic framework that can be extended to suit even more ambitious purposes, in particular going beyond the 'do no harm' focus to how MNEs may engage in political CSR by contributing to human rights fulfilment.

\section{Methodology}

Within a context set by our research endeavour on a theory based connection of PCSR and BHR to contribute to clarifying the role of business in fulfilling human rights, we acknowledge the benefits of 'principled pragmatism' (UN 2008, Ruggie 2013) for creating results that connect theory and practice of international business in the complex field of BHR. We take methodological point of departure in an ambitious version of such pragmatism, which translates into a broad interpretation of corporate responsibilities that includes positive duties (fulfilling human rights) as well as negative (respecting human rights). The methodological point of departure also recognizes the collaborative multi-stakeholder approach to governance and soft law advocated by the business ethics literature.

In line with the pragmatic approach we draw on existing literature for examples and theory-based treatment of specific situations in which MNEs have had positive or negative human rights impacts. The literature offers empirically based theoretical analyses of business impacts on human rights in diverse settings and with a range of different human rights at stake over a period covering two decades. The selected literature examples offer analysis from a range of international business relevant academic disciplines, making them representative for the specific BHR-focused analysis that we wish to perform to help inform the construction of the proposed extension of the UN Framework. Given the emergent stage of a fully-fledged BHR literature, we have found that a literature study based on scholarship of a broad international business nature rather than being explicitly informed by BHR theory offers a solid and relevant point of departure for the analysis of cases that are exemplary illustrations of negative or positive business related human rights impacts. 


\section{From 'do no harm' to doing more good: Extending the UN Framework to connect} Political CSR with Business Responsibilities for Human Rights

Table 1

\begin{tabular}{|c|c|c|c|c|c|}
\hline Company & Sector & Country & $\begin{array}{l}\text { Human Rights } \\
\text { Issue }\end{array}$ & $\begin{array}{l}\text { Company response to } \\
\text { human rights issue }\end{array}$ & $\begin{array}{l}\text { Negative/ } \\
\text { Positive } \\
\text { Human } \\
\text { Rights } \\
\text { Impact }\end{array}$ \\
\hline $\begin{array}{l}\text { Vestas Wind } \\
\text { Systems }\end{array}$ & Wind Energy & Mexico & $\begin{array}{l}\text { Violation of the } \\
\text { rights of } \\
\text { indigenous } \\
\text { people through } \\
\text { wind-farming } \\
\text { project in } \\
\text { Oaxaca }\end{array}$ & Withdrew from the project & Negative \\
\hline Nike & $\begin{array}{l}\text { Clothing/ } \\
\text { Apparel }\end{array}$ & $\begin{array}{l}\text { Several } \\
\text { countries in } \\
\text { Asia and } \\
\text { Latin } \\
\text { America }\end{array}$ & $\begin{array}{l}\text { Labor rights } \\
\text { violations in the } \\
\text { supply chain }\end{array}$ & $\begin{array}{l}\text { Performed due diligence } \\
\text { and employed a multi- } \\
\text { stakeholder approach to } \\
\text { ensure the respect for } \\
\text { labor rights in the supply } \\
\text { chain }\end{array}$ & Negative \\
\hline Novo Nordisk & $\begin{array}{l}\text { Pharmaceutics } \\
\text { (mainly dia- } \\
\text { betes care) }\end{array}$ & China & $\begin{array}{l}\text { Lack of access } \\
\text { to health care in } \\
\text { large parts of } \\
\text { the population - } \\
\text { particularly in } \\
\text { rural areas }\end{array}$ & $\begin{array}{l}\text { Engaged in public-private } \\
\text { partnerships with civil } \\
\text { society and governmental } \\
\text { institutions to improve } \\
\text { diabetes care and enforce } \\
\text { national health } \\
\text { recommendations }\end{array}$ & Positive \\
\hline WesternZagros & Oil and gas & $\begin{array}{l}\text { Iraq } \\
\text { (Kurdistan } \\
\text { area) }\end{array}$ & $\begin{array}{l}\text { Lack of access } \\
\text { to basic human } \\
\text { rights due to } \\
\text { weak and fragile } \\
\text { government }\end{array}$ & $\begin{array}{l}\text { Engaged in various forms } \\
\text { of community } \\
\text { development and } \\
\text { fulfilment of human rights } \\
\text { through partnerships with } \\
\text { local partners and NGOs }\end{array}$ & Positive \\
\hline
\end{tabular}

The literature study is not an evaluation of the CSR policies of the MNEs in question or of the analysis of such policies in the selected literature. Rather, we apply literature-based examples relating to business impact on human rights to illustrate both the value and the limitations of the original UN Framework given its 'do no harm' focus. The value analysis serves to confirm that it makes sense to add on the existing Framework and build on its key concepts in our endeavour to contribute to connecting PCSR and BHR. The analysis of limitations serves to propose elements for an extension to comprise business contributions to human rights fulfilment.

To identify the cases for analysis, we searched for international business related literature that describes and analyses business impact on communities, labour, or the provision of social services or public goods such as 


\section{From 'do no harm' to doing more good: Extending the UN Framework to connect} Political CSR with Business Responsibilities for Human Rights

education, health, or other social human rights. The selection of specific literature-based exemplary cases was made on the basis of three criteria to ensure a relevant coverage of core issues related to our theory basis: (1) representation of both negative and positive human rights impacts; (2) identification of a political human rights problem (where the government does not fully protect/fulfil human rights); and (3) the representation of a corporate strategy to 'substitute' governmental action to fulfil human rights and a corporate strategy to hold the government accountable to its duty to fulfil human rights. Table 1 provides a summarizing overview of the four literature-based cases. Two of these, relating to the MNEs Vestas and Nike, are examples of firms' negative human rights impacts. They confirm the relevance of the original UN Framework because they demonstrate the importance of performing due diligence and engaging in multi-stakeholder collaboration. The two cases related to the MNEs Novo Nordisk and WesternZagros show how corporations can interpret their positive duties differently in different contexts by exercising leverage.

Our analysis and theory contribution takes point of departure in the UN Framework rather than the UNGPs. The reasoning is that the UNGPs operationalize the UN Framework and therefore build on the Framework, which for scholarly purposes constitutes the theory-based advancement of BHR. As a consequence, much of the critique that has been raised against the currently emerging BHR regime championed by the UN addresses the focus and delimitations of the UN Framework, directly or indirectly as they translate into the UNGPs.

While our aim is to respond to the critique of the scope of the Framework for being limited to negative corporate responsibilities to respect human rights, we also acknowledge that the Framework has played an important role for BHR theory and practice since its adoption in 2008, as indicated above. Hence, we take our point of departure in the UN Framework from 2008. The focus of the UN Framework on states or/and corporations divided into the three pillars is illustrated in Figure 1. Rather than developing a new model for positive corporate human rights responsibilities we propose to transform key elements from the negative 'do no harm' to the positive 'do more good'. We therefore start out by analysing the functioning of key elements in the existing Framework to test their relevance against literature-based studies that were performed without a specific BHR and/or UN Framework informed approach. The focus of the first part of that analysis is on the Framework's relevance for dealing with human rights issues within its current scope through providing guidance for human rights due diligence and related steps, including meaningful stakeholder participation. The second part focuses on how businesses in practice may contribute to fulfilling human rights. On this basis of theory and literature studies we develop a proposal for extending the UN Framework to provide guidance for corporate activities in the political sphere to fulfil human rights. 
Figure 1

\section{UN Framework \\ 'Do no harm'}

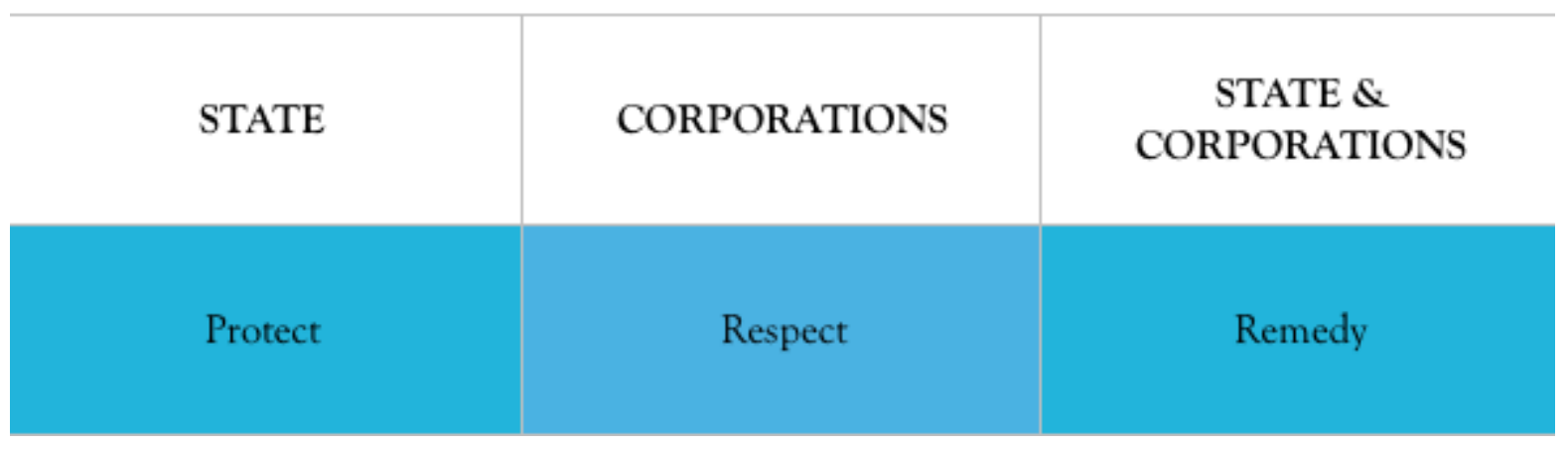

\section{Analysis: Exploring implications of PCSR and the UN Framework towards human rights fulfilment}

\subsection{The relevance of the UN Framework as a platform for developing PCSR guidance}

In 2012 Vestas Wind Systems, a company registered in Denmark, signed a contract with the Mexican company Mareña Renovables to deliver wind turbines for a wind-farming project in the Oaxaca region of Mexico. This case illustrates the potential consequences for the company as well as society of the company's neglect to perform human rights due diligence to identify the project's human rights impacts and its disregard of stakeholder engagement, especially of potentially affected stakeholders (victims). The project was to be located in one of the most important multicultural areas of Mexico, home to a variety of indigenous peoples and ancient cultures (Ramirez 2013). The project was subject to severe critique and protest from local communities in the region. Indigenous groups feared that the wind project would not only infringe upon their territory, but might also have a significant harmful environmental impact on the area. Local communities felt that they had been misinformed and that their opinions had been disregarded in violation of the human rights to consultation and participation in decision-making (Ramirez 2013). A report by the Inter-American Development Bank (IDB) noted that "... the consultation process did suffer from a lack of a systematic process to register issues, concerns and feedback of affected people" (IDB 2013 Section 64). This indicates a lack of attention to processes of due diligence and multi-stakeholder participation, and inadequate awareness of the fact that disregard of stakeholder involvement may in itself be a human rights violation.

The way Vestas went about their Oaxaca project violated the human rights of the indigenous inhabitants as specified by ILO Convention 169 (International Labour Organization 1989) in two major ways. Firstly, 


\section{CBDS Working Paper \\ From 'do no harm' to doing more good: Extending the UN Framework to connect Political CSR with Business Responsibilities for Human Rights}

Vestas did not respect provisions to safeguard natural resources as well as the access of indigenous peoples to their land (articles 14 and 15), thus failing to secure its consequential legitimacy. Secondly, the rights of the indigenous people to consultation and participation in matters that affect them were not sufficiently respected (article 6), weakening procedural legitimacy as well. Due to top-down project management and inadequate due diligence, Vestas was not accepted as a morally legitimate actor in Oaxaca by the civil society and failed to acquire a social licence to operate. After a series of delays, public outrage finally forced the company to resort to a costly withdrawal (Ramirez 2013). Thus, insufficient awareness of the local cultural context framing the company's potential impact not only entailed a negative human rights impact, but also caused significant moral and financial difficulties for Vestas.

The UN Framework provides an outline of the process of human rights due diligence as part of the corporate responsibility to respect human rights, upon which the UNGPs later elaborated details. As indicated, stakeholder engagement is an important feature of human rights due diligence in order for a company to understand its human rights impact. The experience of US based MNE Nike Inc. (Nike) confirms the significance of companies engaging in a bottom-up process of multi-stakeholder participation and collaboration. In the 1990s Nike was heavily criticized for labour rights abuses in the supply chain in Asia and Latin America including forced overtime, below-minimum wages and child labour. To meet societal expectations Nike began to formulate codes of conduct, which obligated the suppliers to commit to ensuring basic labour, environmental and safety standards (Spar \& LaMure 2003, Locke \& Romis 2007). Nonetheless, working conditions did not change significantly, which illustrates that solely relying on codes of conduct often fails due to forced compliance, top-down implementation of Western standards, weak auditing practices and inconsistent interpretation and application (Rasche 2010, Lund-Thomsen \& Lindgreen 2013). When Nike examined the sources of labour rights abuses, the company learned that its procurement practices were a major driver of excessive overtime among suppliers. The company's tight inventory management caused problems when demand was not correctly forecasted or changed on short notice. Such changes could cause suppliers to require overtime in the factories, leading to labour rights violations (Waddock \& Rasche 2012). Related to this, suppliers may subcontract to other suppliers, of which the buyer has no knowledge, in order to meet deadlines. Nike began to embrace multi-stakeholder dialogue and collaboration, which enabled them to better manage the challenges that from the BHR perspective are human rights challenges in their supply chain. As Nike emphasised frequent supplier visits, joint problem solving and a closer relationship to their suppliers, the company succeeded in lowering the prevalence and severity of human rights violations (Spar \& La Mure 2003, Waddock \& Rasche 2012). This bottom-up approach to managing the supply chain helped Nike gain moral legitimacy, because the company adapted their practices to stakeholders' expectations. More specifically, it secured both the company's consequential legitimacy, as human rights violations were 


\section{CBDS Working Paper \\ From 'do no harm' to doing more good: Extending the UN Framework to connect Political CSR with Business Responsibilities for Human Rights}

significantly reduced, and its procedural legitimacy, as stakeholders were involved in a participatory process of decision-making.

\subsection{How firms may to contribute to fulfilling human rights}

The previous section showed the importance of due diligence and multi-stakeholder participation for respecting human rights. This section is concerned with how companies can best contribute to fulfilling human rights, adopting a leverage-based approach.

Novo Nordisk is one of the world's leading companies in diabetes treatment. The company, which is also registered in Denmark, operates in many countries including China, where the diabetes prevalence is $9.6 \%$ (International Diabetes Federation 2013), and where the majority of diabetics does not have access to treatment due to poor health infrastructure and a lack of knowledge and awareness (Brown \& Knudsen 2012). The company has worked actively to fulfil human rights based on an explicit policy on human rights as part of its general stakeholder oriented CSR policy since the late 1990s (Morsing and Schultz 2006). To address governmental shortcomings in providing diabetes care in China, Novo Nordisk has sought to influence the political agenda by engaging in multi-stakeholder initiatives with NGOs, local stakeholders and the Chinese Ministry of Health to improve diabetes care in the public health care systems, ensure enforcement of national health recommendations and diabetes treatment guidelines and improve training and public health system integration (Brown and Knudsen 2012, 2013). The company has trained more than 55,000 physicians, each treating on average 230 patients a year, and has offered education and support for 280,000 diabetes patients as part of its focus on community development and diabetes prevention (Novo Nordisk 2011). By consistently applying a bottom-up multi-stakeholder approach while also working to expand its own market, Novo Nordisk ensured its procedural legitimacy. By raising awareness and providing basic knowledge of diabetes and substantial improvement of diabetes treatment across the country, the rights of patients were strengthened and the consequential legitimacy for the firm was increased.

The Novo Nordisk case illustrates that a company's efforts may play a complementary and supporting role, strengthening governmental action on diabetes. This counters concerns noted above about governments taking a passive stance and letting MNEs deliver social services corresponding to citizens' social human rights claims. Novo Nordisk did not provide diabetes care where the government failed to, but enabled and pressured the government to do its job better. In this way, rather than undermining the responsibility of the Chinese government to provide diabetes care, Novo Nordisk acted in practice as a secondary duty bearer that reinforced the responsibility of the government as the primary duty bearer. This occurred in collaboration with the national government as well as other relevant stakeholders at local and national levels. The focus, 


\section{CBDS Working Paper \\ From 'do no harm' to doing more good: Extending the UN Framework to connect Political CSR with Business Responsibilities for Human Rights}

extent and success of Novo Nordisk's CSR activities demonstrate how a company can acquire moral legitimacy by effectively leveraging its knowledge and resources to improve human rights fulfilment by the government where such fulfilment is inadequate despite the presence of resources.

A different situation arises when companies operate in areas where the government lacks the necessary capacity and resources to fulfil even the most basic human rights. In such circumstances the company should engage substantially in directly fulfilling human rights. The Canadian oil company WesternZagros, which set up in the Kurdistan area in North-Eastern Iraq in 2003 shortly after the US-led invasion of Iraq, found itself in an area that was extremely underdeveloped with minimal government presence. It also found a poor population that had limited access to human rights due to long periods of conflict (Jamali, Karam \& Blowfield 2015). WesternZagros was one of very few companies in this remote area (van Duren \& Dhalla 2012). The company's role in the lives of the local population arguably entailed a morally significant connection between the company and the human rights issues of the community. As part of its CSR strategy, the company has implemented measures to be perceived as a morally legitimate actor in the community by compensating for governmental absence through services delivered by the company, and contributing to community development. The company's projects included building physical infrastructure, such as wells and irrigation systems, providing health care and establishing educational facilities. The company chose to "conduct business in a way that optimised the benefits for the citizens of the Kurdistan region" (van Duren \& Dhalla 2012: 286-287) and therefore trained and employed people from the local population in order to improve standards of living and upgrade technical skills and human resources in the area, thus securing consequential legitimacy. It is difficult to make the case that the corporation's provision of basic human rights has undermined the governmental responsibility, as governmental presence and capacity was minimal to begin with and any contributions to fulfilling human rights in such a state must be seen as positive. Through leverage-based engagement related to the company as a strong actor in the community, most of the projects have been carried out in multi-stakeholder partnerships with a variety of NGOs and local partners, enhancing the company's procedural legitimacy. The company has also developed plans to work with local educational authorities in order to expand governmental capacity to ensure access to education (van Duren \& Dhalla 2012, Jamali, Karam \& Blowfield 2015). This reaffirms the role of the state as the primary duty bearer and the potential of leverage-based engagement, which in the case of WesternZagros contributes directly to the fulfilment of human rights.

\subsection{Drawing insights from the cases to move from 'respect' to 'fulfil' human rights}

The Vestas and Nike cases demonstrate the significance of the respect dimension of the UN Framework. They confirm the value of performing due diligence and engaging in multi-stakeholder dialogue and 


\section{CBDS Working Paper \\ From 'do no harm' to doing more good: Extending the UN Framework to connect Political CSR with Business Responsibilities for Human Rights}

collaboration, both of which are recommended by the UN Framework. Due diligence proved useful in revealing risks of complicity in human rights abuses in Nike's extended supply chain, while the case of Vestas exemplifies the economic risk to the company of not performing human rights due diligence. The Vestas and Nike cases also demonstrate that in order to solve human rights problems, a multi-stakeholder approach that involves relevant stakeholders in decision-making is necessary. Such a collaborative approach, which entails positive steps to consult and ensure participation, allowed Nike to drastically reduce human rights violations in their supply chain and gain moral legitimacy, while Vestas' neglect to collaborate with local stakeholders resulted in public condemnation forcing the company to eventually withdraw from the project, suffering economic loss. In this way, both cases show the powerful effects of normative institutional pressure from civil society, forcing MNEs to adapt to societal expectations. The cases confirm the relevance of the UN Framework as a foundation for defining the corporate responsibility in a human rights context within its 'do no harm' delineation. But how about the fulfilment aspect?

The examples of how Novo Nordisk and WesternZagros contributed to human rights fulfilment demonstrate the relevance of adding the fulfil dimension to the UN Framework based on the company's leverage. The leverage-based approach takes point of departure in the company's ability to use its expertise, sector role and economic power to exert influence. Already applied by the UN Framework with regard to the corporate responsibility to respect, leverage is also a useful approach to demarcate the corporate responsibility to fulfil human rights where the primary duty bearer fails in its duty. In combination with the practice of human rights due diligence, applying leverage may serve to prevent corporations from being held responsible for human rights failures caused by others, but it simultaneously calls on them to identify governmental human rights failures within the company's reach and act where they have leverage to make a difference. The Novo Nordisk and WesternZagros cases show how corporations are indeed capable of exercising their leverage to make substantial contributions to communities where governments lack the capacity or inclination to fulfil human rights. Moreover, the cases suggest that corporations can successfully collaborate with and apply pressure to state agencies, and in this way reaffirm the state as the primary duty bearer rather than simply substituting government action. Thus, seen from a human rights perspective, MNEs may well assume positive duties as secondary duty bearers, complementing governments or simply filling governance gaps.

\section{Extending the UN Framework to contribute to PCSR with a focus on human rights fulfilment}

Based on insights from the analysis we propose to extend the UN Framework to include positive duties for MNEs and offer guidance for PCSR in relation to human rights fulfilment. Figure 2 shows a simple graphical depiction in which the corporate responsibility to fulfil is the positive duty corollary to the corporate 


\section{CBDS Working Paper \\ From 'do no harm' to doing more good: Extending the UN Framework to connect Political CSR with Business Responsibilities for Human Rights}

responsibility to respect. Drawing on the combination of PCSR and BHR theory that guides this article, the extension of the UN Framework is based on the three fundamental concepts of moral legitimacy, due diligence and leverage. It maintains the three-pillared structure of the UN Framework, preserving the State Duty to Protect and the need for effective remedy mechanisms, but outlines a dual corporate responsibility based on not only the impact of the corporate activities, but also on the company's leverage. Like the original UN Framework, the extension approaches the outlined human rights responsibilities as legally voluntary, but morally binding and subject to the scrutiny and judgment of civil society.

\section{Figure 2}

\section{The Extended UN Framework 'Beyond doing no harm'|}

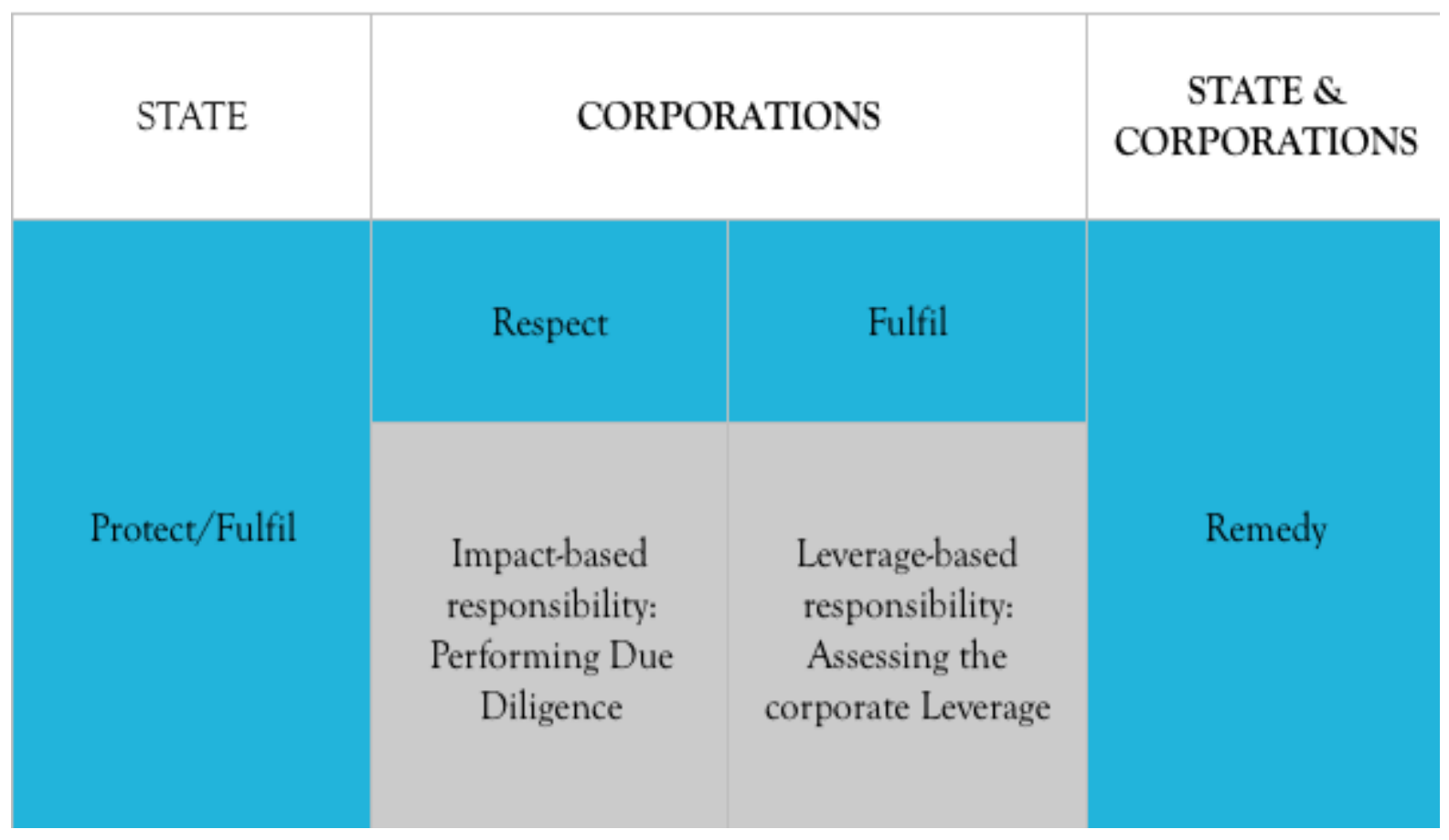

The due diligence process related to reducing adverse human rights impacts evolves in steps from policy commitment over communication, monitoring, integration and response that each require reflection at the appropriate management level. Similarly, the process to identify and handle fulfilment needs proceeds in steps. To identify their human rights impact and clarify the actions needed and those that they should perform, managers should consider a set of context-specific issues. In the following we identify these based on the literature-based cases and the combined PCSR-BHR theory framework. The process helps managers identify the potential positive impact of their firm and make decisions on how to extend it to those in need essentially performing political tasks that increase the provision of public goods that are human rights. 


\section{CBDS Working Paper \\ From 'do no harm' to doing more good: Extending the UN Framework to connect Political CSR with Business Responsibilities for Human Rights}

In accordance with the objective noted above to build on the existing UN Framework in order to draw on the power that it has already had with MNEs and with regard to CSR codes, the extended Framework applies the terminology and structure of the 2008 Framework. The extended Framework adds a new sub-pillar under the corporate responsibility and enhances the role of leverage for the new fulfilment part (see figure 3).

Consistent with the original UN Framework, the extended Framework bases the corporate responsibility to respect human rights on the impact of the MNE. This requires companies to perform due diligence. As part of this, they should engage in stakeholder dialogue. From the PCSR perspective, this helps them achieve moral legitimacy. The corporate responsibility to fulfil human rights is based on the leverage of the MNE. By contributing to pertinent human rights needs the company engages in PCSR and enhances its moral legitimacy.

For both the negative and positive human rights focus, managers should clarify the human rights issues at stake, the potential human rights impact of the company, and the leverage of the firm in the context in which it operates. As is the case for the 'do no harm' approach, managers may need to obtain human rights knowledge for identifying needs for human rights fulfilment and their capacity to take on such a political role. In line with the original UN Framework this may be acquired by collaborating with human rights experts.

It follows from the due diligence emphasis of the original Framework that to identify salient issues that call the company to take action to avoid infringing on human rights (the negative focus), managers need to ask themselves: What is the given country context with respect to human rights? What direct and indirect human rights impact do we have? How do we eliminate our negative human rights impact? What stakeholders do we need to collaborate with to eliminate our negative human rights impact and gain moral legitimacy?

Building on this, it follows from the leverage emphasis of the extended Framework that to identify and determine the type of action that is relevant to their business to contribute to fulfilling human rights (the positive focus), managers need to clarify the following issues: What human rights do the primary duty bearers in the given country not adequately fulfil? Which of these do we have the knowledge and capabilities to do something about? Can we strengthen the primary duty bearer's fulfilment of the given human rights? What stakeholders do we need to collaborate with to ensure the fulfilment of the given human rights and gain moral legitimacy?

The process of engaging with these issues should be anchored with the top management to help determine the political role to be assumed by the company. When that has been settled the specific actions to be taken can 


\section{CBDS Working Paper \\ From 'do no harm' to doing more good: Extending the UN Framework to connect Political CSR with Business Responsibilities for Human Rights}

be assigned to managers at other levels and specific tasks assigned responding to the specific operational steps.

Figure 3

\section{The Extended UN Framework 'Beyond doing no harm'}

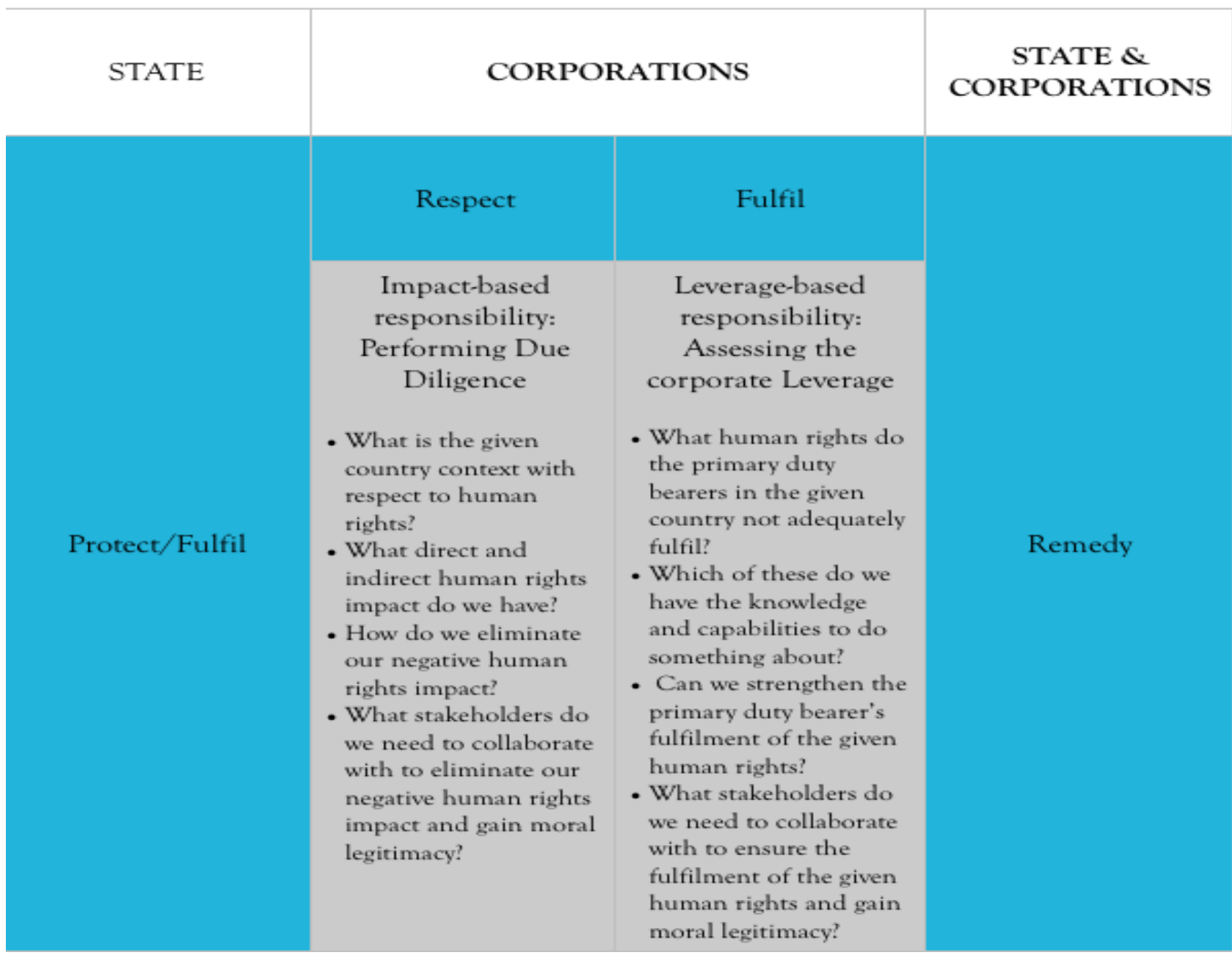

The extension of the UN Framework serves two main purposes. First, it closes the gap in the literature on PCSR and BHR by providing theory-based guidance for responsibilities of corporations to assist in the fulfilment of human rights. The Extended Framework combines the qualities of the PCSR and BHR literature by identifying a series of issues to be clarified for companies to manage their human rights responsibilities as they undertake 'political' action. The issues to be considered and clarified do not constitute a definite checklist for managers to follow, but rather serve as a starting point for developing an appropriate human rights mind-set for managers to adopt at appropriate levels of the company. A framework is an outline that 


\section{CBDS Working Paper \\ From 'do no harm' to doing more good: Extending the UN Framework to connect Political CSR with Business Responsibilities for Human Rights}

does not tell managers what human rights problems to solve and how to solve them, but it can help them assess their human rights responsibility and provide an approach to handling human rights issues. This requires companies to urge managers to be aware of and consider human rights and political issues as well as business matters. Employing inter-disciplinary skills and knowledge may prove useful.

Like the original UN Framework, the Extended Framework offers guidance to SMEs as well as MNEs, which are typically large firms. The UN Framework's recognition that human rights issues are relevant to companies of all sizes is particularly important in the context of many developing countries whose business communities are dominated by SMEs. Equally, the Extended Framework may apply to companies of all sizes, bearing in mind that leverage is highly context specific and not necessarily proportional to the size of a company.

Second, the Extended UN Framework acknowledges that businesses, especially MNEs, operate in a world with varying governmental presence and capacity and varying fulfilment of human rights. From a business ethics oriented perspective, assigning exclusive duties to single actors in society, as is the case in the UN Framework, may be problematic because this assumes an unrealistic moral optimum. The UN Framework is based on a recognition of governance gaps that may appeal particularly to political scientists and lawyers, but perhaps because of this it has been subject to strong critique among important strands of the international business literature for not taking institutional incapacities to fulfil human rights into account and not offering solutions to companies for how to take responsibility in that regard. The emergence of PCSR theory demonstrates that an abundance of institutional voids and weak governmental presence in many parts of the world today underscores the need for practical as well as moral legitimacy purposes for companies to contribute to human rights fulfilment.

The Extended UN Framework proposed in here offers guidance for firms on how to understand and engage with positive responsibilities depending on the institutional context of the specific countries. This does not alter the fact that the state is the primary bearer of positive human rights duties, and that in an optimal situation of total state benevolence and capacity to fulfil human rights, corporations need only consider their negative duties to do no harm. The original UN Framework can be seen as an appropriate framework in such optimal situations. However, the reality is strikingly different from the optimal situation in many countries around the world as human rights fulfilment is neglected by numerous states around the world. The Extended Framework goes beyond the original UN Framework's 'do no harm' focus by taking point of departure in the human rights reality of the country and sector in question with regard to human rights needs and by offering companies guidance for doing more good where human rights are inadequately fulfilled. 


\section{CBDS Working Paper \\ From 'do no harm' to doing more good: Extending the UN Framework to connect Political CSR with Business Responsibilities for Human Rights}

\section{Conclusion}

To contribute to filling the theory gap on operationalising PCSR with particular regard to the role of MNEs in human rights fulfilment, this article has combined the literatures on PCSR and BHR by extending the UN Framework from guiding companies to 'do no harm' toward also 'doing more good'. Specifically, this contributes to determining the political responsibilities of corporations to play a role in fulfilling human rights, and adds to the theory-based foundations for turning that into operational steps for managers. The proposed Extended UN Framework explicitly encompasses positive action by businesses to exercise their leverage to fulfil human rights where the government fails to do so.

The proposal to extend the UN Framework to offer theory-informed guidance to firms in relation to undertaking human rights-related PCSR contributes to the PCSR literature by introducing a normative operational framework for assessing political corporate responsibilities in relation to human rights, and to the BHR literature by extending the UN Framework's guidance to encompass leverage-based positive duties. The prevalence of human rights problems in all countries along with an outspoken need for increased fulfilment of social and economic rights underscores the need for more ambitious solutions to institutional voids resulting from governance gaps that lead to persisting human rights challenges. In light of such challenges, we contend that pro-active corporate engagement in human rights initiatives may under certain circumstances function as a complement to governmental action in developing countries. The Extended Framework emphasises the importance of managers not only possessing business skills, but also acquiring an enhanced understanding of politics and human rights. Like the original UN Framework highlights issues and processes of pertinence to the Corporate Responsibility to Respect human rights, the Extended Framework highlights issues of relevance to human rights fulfilment as PCSR. These are of relevance to managers operating globally and particularly in localities where human rights problems are acute, typically outside of MNE home states. Thus, the Extended Framework optimizes PCSR by offering guidance for firms to go beyond the responsibility to respect in providing solutions to persisting governmental failures to fulfil human rights (and therefore assume political roles). This contributes towards a better understanding of the human rights responsibilities of MNEs and their potential to solve human rights problems.

Several research perspectives arise from the proposal to extend the UN Framework to encompass corporate responsibilities to fulfil human rights. This article constitutes an early step towards what may evolve into more detailed theory-informed guidance for how companies can assess their capacity and responsibilities. More in-depth empirical research is needed to determine how companies can apply the framework and assess their leverage. The Extended Framework provides an input for assessing corporate responsibility in society and addresses how corporations should assess their capabilities and actively contribute to the fulfillment of human rights. However, one of the central challenges in this context is how to motivate and persuade 


\section{CBDS Working Paper \\ From 'do no harm' to doing more good: Extending the UN Framework to connect Political CSR with Business Responsibilities for Human Rights}

companies to take responsibility and turn this into actively reducing negative human rights impacts and increasing their positive contributions to human rights, in other words, their human rights fulfilment. While the literature on PCSR outlines the pursuit of moral legitimacy as a driver for companies engaging in PCSR, doubt remains whether this is enough to ensure a sustainable corporate impact on the fulfilment of human rights, or whether it may be just another form of self-interest.

More research also needs to be performed to ascertain whether companies really need to fulfil human rights in order to obtain moral legitimacy, or whether avoiding complicity in human rights abuses is sufficient for them to be perceived as legitimate actors in a global world of business. Further research should look into the corporate motivations for respecting and fulfilling human rights with a view to discussing how to engage the private sector in solving human rights problems resulting from governance gaps. To maximize the contribution of the private sector to human rights needs, future research may also consider what role SMEs have, especially in countries with institutional voids, in fulfilling human rights, and whether their often locally embedded character increases or reduces their leverage as compared to MNEs. Exploring these issues further would inform the applicability of the Extended Framework and challenge the CSR literature's dominant focus on the responsibility of Western MNEs with a particular regard to operations in developing countries. 


\section{CBDS Working Paper \\ From 'do no harm' to doing more good: Extending the UN Framework to connect Political CSR with Business Responsibilities for Human Rights}

\section{References}

Arnold, D.G. 2010. 'Transnational Corporations and the Duty to Respect Basic Human Rights'. Business Ethics Quarterly, 20:3, 371-399.

Brown, D. \& Knudsen, J. S. 2012. 'Managing CSR Globally and Locally: Lessons from a CSR Leader'. Business and Politics, 14:3, 1-29.

Brown, D. \& Knudsen, J. S. 2013. 'Novo Nordisk: Managing Sustainability at Home and Abroad'. London, ON Richard Ivey School of Business

Buhmann, K. 2006. 'Corporate Social Responsibility - what role for law? Some Legal Aspects of CSR'.

Corporate Governance - The International Journal of Business in Society, 6:2, 188-202.

Buhmann, K. 2009. 'Regulating Corporate Social and Human Rights Responsibilities at the UN plane: Institutionalising new forms of law and law-making approaches?'. Nordic Journal of International Law, 78:1, 1-52.

Buhmann, K. 2012. 'Development of the 'UN Framework': A pragmatic process towards a pragmatic output'. In Radu Mares (ed.) The UN Guiding Principles on Business and Human Rights: Foundations and Implementation. Martinus Nijhoff Publishers: 85-106.

Buhmann, K. 2013. 'The Danish CSR reporting requirement as reflexive law: Employing CSR as a modality to promote public policy'. European Business Law Review, 2, 187-216.

Buhmann, K. 2015. 'Human Rights Due Diligence: On guidance from National Contact Point practice under OECD’s Guidelines on Multinational Enterprises and challenges in eliciting such guidance'. International Review of Compliance and Business Ethics / Revue Internationale de Compliance et de l'Ethique des Affaires, 27: 17-19

Buhmann, K. 2016. 'Public regulators and CSR: The 'Social Licence to Operate' in recent United Nations instruments on Business and Human Rights and the juridification of CSR'. Journal of Business Ethics, 136(4), 699-714, DOI 10.1007/s10551-015-2869-9

Business and Human Rights Resource Center Website. Available: http://business-humanrights.org Accessed 08.09.2016

Campbell, T. 2007. 'Why would corporations behave in socially responsible ways? An institutional theory of corporate social responsibility'. Academy of Management Review, 32:3, 946-967.

Cragg, W. 2012. 'Ethics, Enlightened Self-Interest, and the Corporate Responsibility to Respect Human 


\section{CBDS Working Paper \\ From 'do no harm' to doing more good: Extending the UN Framework to connect Political CSR with Business Responsibilities for Human Rights}

Rights'. Business Ethics Quarterly, 22:1, 9-36.

De Felice, D. (2015) 'Challenges and Opportunities in the Production of Business and Human Rights Indicators to Measure the Corporate Responsibility to Respect'. Human Rights Quarterly, 37(2). 511-555.

Demuijnck, G. and B. Fasterling (2016). The Social License to Operate, Journal of Business Ethics 136 (4), 675-85.

Dentchev, N. A., van Balen, M. \& Haezendonck, E. 2015: 'On voluntarism and the role of governments in CSR: towards a contingency approach'. Business Ethics: A European Review, 24:4, 378-397.

Deva, Surya (2013) 'Treating Human Rights Lightly: A Critique of the Consensus Rhetoric and the Language Employed by the Guiding Principles'. In Deva, Surya and David Bilchitz (eds) Human Rights Obligations of Business: Beyond the Corporate Responsibility to Respect?, Cambridge: Cambridge University Press: 78-104

DiMaggio, P.J. \& Powell, W.W. 1991. 'Introduction'. In Powell, W.W. and DiMaggio, P.J. (Eds.), The New Institutionalism in Organizational Analysis : 1-38. Chicago, IL: University of Chicago Press

Fasterling, B. and G. Demuijnck (2013) 'Human Rights in the Void? Due Diligence in the UN Guiding Principles on Business and Human Rights'. Journal of Business Ethics, 116 (4), 799-814.

Frynas, J. G. and Stephens, S. (2015), 'Political Corporate Social Responsibility: Reviewing Theories and Setting New Agendas'. International Journal of Management Reviews 17: 483-509. doi:10.1111/ijmr.12049

Gjølberg M. 2010. 'Varieties of corporate social responsibility (CSR): CSR meets the "Nordic Model”'. Regulation \& Governance, 4:2, 203-229.

Gjølberg, M. 2011. 'Explaining Regulatory Preferences: CSR, Soft Law, or Hard Law? Insights from a Survey of Nordic Pioneers in CSR'. Business and Politics, 13:2, 1-33.

Gond, J-P, Kang, N. \& Moon, J. 2011. 'The government of self-regulation: on the comparative dynamics of corporate social responsibility'. Economy and Society, 40:4, 640-671.

Giuliani, E., \& Macchi, C. 2014. 'Multinational corporations' economic and human rights impacts on developing countries: A review and research agenda'. Cambridge Journal of Economics, 38: 479- 517

Habermas, J. 2003. 'The Postnational Constellation: Political Essays'. The Journal of Value Inquiry, 37:1, 131-136. 


\section{CBDS Working Paper \\ From 'do no harm' to doing more good: Extending the UN Framework to connect Political CSR with Business Responsibilities for Human Rights}

Hertz, N. 2001. 'Better to Shop than to Vote?'. Business Ethics: A European Review, 10:3, 190-193.

Horrigan, B.T. 2010. Corporate Social Responsibility in the 21st Century: Debates, Models and Practices Across Government, Law and Business. Cheltenham: Edward Elgar Publishing Limited.

Human Rights Watch 2016. 'World Report 2016'. Available:

https://www.hrw.org/sites/default/files/world_report_download/wr2016_web.pdf. Accessed: 08.09.2016

Idemudia, U. \& Ite, U. 2006. 'Corporate-Community Relations in Nigeria's Oil Industry: Challenges and Imperatives'. Corporate Social Responsibility and Environmental Management, 13, 194-206.

Inter-American Development Bank (IDB) 2011. Mareña Renovables Wind Power Project (ME-L1107). Environmental and Social Management Report (ESMR) (21 November, 2011). Available:

http://idbdocs.iadb.org/wsdocs/getdocument.aspx?docnum=36537741. Accessed: 08.09.2016

International Diabetes Federation (2013): IDF Diabetes Atlas 6th Edition. Available:

http://www.idf.org/sites/default/files/EN_6E_Atlas_Full_0.pdf. Accessed: 08.09.2016

International Labour Organization (1989): Convention 169 - Indigenous and Tribal Peoples Convention, http://www.ilo.org/dyn/normlex/en/f?p=NORMLEXPUB:12100:0::NO::P12100_ILO_CODE:C169. Accessed 08.09.2016

Jamali, D., Karam, C. \& Blowfield, M. 2015. 'Development-Oriented Corporate Social Responsibility'. Volume 1 Multinational Corporation and the Global Context. Sheffield: Greenleaf Publishing.

Jamali, D., Safieddine, A. \& Rabbath, M. 2008. 'Corporate Governance and Corporate Social Responsibility Synergies and Interrelationships'. Corporate Governance: An International Review, 16:5, 443-459.

Jones, T.M. 1995. 'Instrumental Stakeholder Theory: A Synthesis of Ethics and Economics'. Academy of Management Review, 20:2, 404-437.

Kinley, D., Nolan J. \& Zerial, N. 2007. 'The Norms are Dead. Long Live the Norms!: The Politics Behind the UN Human Rights Norms for Corporations'. In McBarnet, Doreen, Aurora Voiculescu and Tom Campbell (eds), The New Corporate Accountability: Corporate Social Responsibility and the Law: 459-475. Cambridge: Cambridge University Press.

Knox, J.H. 2012. 'The Ruggie Rules: Applying human rights law to corporations', in Mares, Radu (ed) The UN Guiding Principles on Business and Human Rights: 51-83. Antwerp: Brill. 


\section{CBDS Working Paper \\ From 'do no harm' to doing more good: Extending the UN Framework to connect Political CSR with Business Responsibilities for Human Rights}

Kolk, A. and van Tulder, R. 2004. 'Ethics in international business: multinational approaches to child labour.' Journal of World Business 39(1): 49-60

Kolk, A. 2016. 'The Social Responsibility in international business: from ethics and the environment to CSR and sustainable development'. Journal of World Business 51(1) 23-34.

Kolk, A. \& Lenfant, F. 2013. 'Multinational, CSR and Partnerships in Central African Conflict Countries'.

Corporate Social Responsibility and Environmental Management, 20, 43-54.

Kolstad, I. 2012. 'Human rights and positive corporate duties: the importance of corporate-state interaction'.

Business Ethics: A European Review, 21:3, 276-285.

Locke, R. \& Romis, M. 2007. 'Improving Work Conditions in a Global Supply Chain'. MIT Sloan

Management Review, 48:2, 54-62.

Lund-Thomsen, P. \& Lindgreen, A. 2013. 'Corporate Social Responsibility in Global Value Chains -

Where Are We Now? Where Are We Going?'. Journal of Business Ethics, 123:1, 11-22.

Lund-Thomsen P., Lindgreen A. \& Vanhamme, J. 2014. 'Industrial clusters and corporate social responsibility in developing countries: what we know, what do not know, and what we need to know'. Journal of Business Ethics, DOI 10.1007/s10551-014-2372-8.

Maon, F., Lindgreen, A. \& Swae, V.2009. 'Designing and implementing Corporate Social Responsibility: An integrated framework grounded in theory and practice'. Journal of Business Ethics, 2009: 87:1, 1-89.

Margolis, J.D. \& Walsh, J.P. 2003. 'Misery Loves Companies: Rethinking Social Initiatives by Business'. Administrative Science Quarterly, 48:2, 268-305.

Martin, J. 2012. "'The End of the Beginning?": A comprehensive look at the U.N.'s Business and Human Rights Agenda from a bystander perspective.' Fordham Journal of Corporate and Financial Law. 17: 871-941

Matten, D., Crane, A. \& Chapple, W. 2003. 'Behind the Mask: Revealing the true face of corporate citizenship'. Journal of Business Ethics, 45:1-2, 109-120.

Matten, D. \& Crane, A. 2005. 'Corporate Citizenship: Towards an Extended Theoretical Conceptualization'. Academy of Management Review, 30:1, 166-179. 


\section{CBDS Working Paper \\ From 'do no harm' to doing more good: Extending the UN Framework to connect Political CSR with Business Responsibilities for Human Rights}

Matten, D. \& Moon, J. 2008. "Implicit" and "Explicit" CSR: A conceptual framework for a comparative understanding of Corporate Social Responsibility'. Academy of Management Review, 33:2, 404-424.

Melish, T.J. and Meidinger, E. 2012. 'Protect, Respect, Remedy and Participate: 'New Governance' Lessons for the Ruggie Framework'. In Mares, Radu (ed) The UN Guiding Principles on Business and Human Rights: 311-332. Antwerp: Brill.

Morsing, M. \& Scultz., M. 2006. 'Corporate social responsibility communication: stakeholder information, response and involvement strategies'. Business Ethics: A European Review, 15, 323-338.

Nolan, J. 2005. 'The United Nation's compact with business: hindering or helping the protection of human rights?'. University of Queensland Law Journal, 24, 445-466.

Nurunnabi, M. 2015: 'Tension between politico-institutional factors and accounting regulation in a developing economy: insights from institutional theory’. Business Ethics: A European Review, 24:4, 398424.

Novo Nordisk 2011. 'Changing Diabetes in China'. Available:

https://www.novonordisk.com/content/dam/Denmark/HQ/Sustainability/documents/blueprint-changing-diabetes-inchina.pdf. Accessed: 08.09.2016

Osuji, O. K., \& Obibuaku, U.L. 2016. 'Rights and corporate social responsibility: Competing or complementary approaches to poverty reduction and socioeconomic rights?' Journal of Business Ethics. 136(2) 329-347, doi: 10.1007/s10551-014-2523-y.

OECD 2016). OECD Due Diligence guidance for meaningful stakeholder engagement in the extractive sector. (preliminary version) Paris: Organisation for Economic Collaboration and Development.

Palazzo, G. \& Scherer, A.G. 2006. 'Corporate Legitimacy as Deliberation. A Communicative Framework'. Journal of Business Ethics, 66:1, 71-88.

Ramirez, J. 2013. 'Vestas and the Indigenous Communities in Oaxaca, Mexico: Clean Energy gets Messy'. Frederiksberg: CBS: Copenhagen Business School.

Rasche, A. 2010. 'The limits of corporate responsibility standards'. Business Ethics: A European Review, $19: 3,280-291$.

Rasche, A. \& Gilbert, D. 2012. 'Institutionalizing global governance: the role of the United Nations Global 


\section{CBDS Working Paper \\ From 'do no harm' to doing more good: Extending the UN Framework to connect Political CSR with Business Responsibilities for Human Rights}

Compact'. Business Ethics: A European Review, 21:1, 100-114.

Roepstorff, A. 2010 CSR: Virksomheders sociale ansvar som begreb og praksis. Copenhagen: Hans Reitzels Forlag

Ruggie, J.G. 2016. 'Hierarchy or ecosystem? Regulating human rights risks of Multinational Enterprises'. Forthcoming in C. Rodriguez-Garavito (ed.) Business and Human Rights: beyond the end of the beginning. Available at SSRN: http://ssrn.com/abstract=2776690 (accessed 29 September 2016)

Ruggie, J.G. 2013. Just business. New York: W.W.Norton Publishing.

Sanders, Astrid. 2015. "The impact of the "Ruggie Framework" and the "United Nations Guiding Principles on Business and Human Rights" on transnational human rights litigation'. Martin, J. and Bravo, K.E. (eds) The Business and Human Rights Landscape: Moving Forward, Looking Back. 288-315. Cambridge University Press.

Scherer, A.G. \& Palazzo, G. 2007. 'Toward a Political Conception of Corporate Responsibility: Business and Society seen from a Habermasian Perspective'. Academy of Management Review, 32:4, 1096-1120.

Scherer, A.G. \& Palazzo, G. 2011. 'The New Political Role of Business in a Globalized World - A Review of a New Perspective on CSR and Its Implications for the Firm, Governance, and Democracy'. Journal of Management Studies, 48:4, 899-931.

Scherer, A.G., Rasche, A., Palazzo, G. \& Spicer, A. 2016. 'Managing for Political Corporate Social Responsibility: New Challenges and Directions for PCSR 2.0'. Journal of Management Studies 53:3; doi 10.1111/joms.12203.

Shelton, D. L. 2014. Advanced Introduction to International Human Rights Law. Cheltenham, UK: Edward Elgar Spar, D.L. \& La Mure, L.T. 2003. 'The Power of Activism: Assessing the Impact of NGOs on Global Business'. California Management Review, 45:3, 78-101.

Suchman, M.C. 1995. 'Managing Legitimacy: Strategic and Institutional Approaches'. Academy of Management Review, 20:3, 571-610.

Sundaram, A.K. \& Inkpen, A.C. 2004. 'The Corporate Objective Revisited'. Organization Science, 15:3, $350-363$.

Swanson, D.L. 1999. 'Towards an Integrative Theory of Business and Society: A Research Strategy for Corporate Social Performance'. Academy of Management Review, 24:3, 506-521. 


\section{CBDS Working Paper \\ From 'do no harm' to doing more good: Extending the UN Framework to connect Political CSR with Business Responsibilities for Human Rights}

Tomuchat, C. 2008. Human Rights: Between Idealism and Realism. Oxford: Oxford University Press.

UN 1966. 'International Covenant on Economic, Social and Cultural Rights'. Available:

http://www.ohchr.org/EN/ProfessionalInterest/Pages/CESCR.aspx. Accessed: 08.05.2016

UN 2003. Sub-Commission on the Promotion and Protection of Human Rights. Norms on the

Responsibilities of Transnational Corporations and Other Business Enterprises with regard to Human

Rights 2003. UN doc. E/CN.4/Sub.2/2003/12/Rev.2.

UN 2004. Commission on Human Rights (2004) Decision 2004/116, UN Doc. E/CN.4/2004/L.73/Rev.1, 16 April 2004

UN 2008. Protect, respect and remedy: A framework for business and human rights, Report of the Special Representative of the Secretary-General on the issue of human rights and transnational corporations and other business enterprises, John Ruggie, UN Doc. A/HRC/8/5 (2008), 7 April 2008

UN 2011. Guiding Principles on Business and Human Rights: Implementing the United Nations 'Protect, Respect and Remedy' Framework.

Van Duren, E. \& Dhalla, R. 2012. 'Business Strategy and CSR in Fragile States: The Case of WesternZagros' Kurdistan Venture'. World Journal of Social Sciences, 2:7, 279-290.

Van Huijstee, M, de Leeuw, L. \& Wilde-Ramsing, J. 2016. 'Should I stay or should I go: Exploring the role of disengagement in human rights due diligence'. Amsterdam: SOMO/Centre for Research on Multinational Corporations

Vogel, D. 2008. 'Private Global Business Regulation'. Annual Review of Political Science, 11:1, 261-282.

Waddock, S. \& Rasche, A. 2012. 'Building the Responsible Enterprise: Where Vision and Values Add Value'. Stanford: Stanford University Press.

Wettstein, F. 2013. 'Making noise about silent complicity: The Moral Inconsistency of the "Protect, Respect and Remedy" Framework', in Deva, S. \& Bilchitz, D. (Eds.), Human Rights Obligations of Business: 243268. Cambridge: Cambridge University Press.

Wettstein, F. 2015. 'Normativity, Ethics and the UN Guiding Principles on Business and Human Rights: A Critical Assessment'. Journal of Human Rights, 14:2, 162-182.

Zerk, J. 2006. Multinationals and Corporate Social Responsibility: Limitations and Opportunities in 
From 'do no harm' to doing more good: Extending the UN Framework to connect Political CSR with Business Responsibilities for Human Rights

International Law. Cambridge: Cambridge University Press. 